REVIEW OF HISTORICAL SCIENCES 2018, VOL. XVII, NO. 3

http://dx.doi.org/10.18778/1644-857X.17.03.11

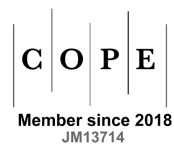

MatgorZATA KARKOCHA

UNIVERSITY OF LODZ*

\title{
St. Anne's prebend in Małogoszcz in the mid-nineteenth century
}

IN the Diocesan Archive in Kielce, in the cover of Małogoszcz. Dokumenty różne z XIX wieku (luzem, nieuporząkowane) [Małogoszcz. Miscellaneous documents from the $19^{\text {th }}$ century (loose, disordered)], there is a fundi instructi inventory of the parish church in Małogoszcz, drawn up on July 5/17, 1856 after the death of the local parish priest, Father Tomasz Swiatkowski ${ }^{1}$. This extensive document has already been the subject of two editions of 'Przeglad Nauk Historycznych' [The Review of Historical Sciences]. Fragments published to date described the architecture and decor of the parish church ${ }^{2}$, as well as the salary, income and expenses

* Faculty of Philosophy and History, Institute of History, Department of Modern History / Wydział Filozoficzno-Historyczny, Instytut Historii, Katedra Historii Nowożytnej, e-mail: malgorzata.karkocha@uni.lodz.pl.

${ }^{1}$ Inventory fundi instructi of the parish church beneficium in the town of Małogoszcz after the death of Fr. Tomasz Swiatkowski, parish priest per person Hon. Fr. Nestor Bieroński, deputy regens of the Kielce Seminary, newly established parish priest in Małogoszcz in 1856, Diocesan Archive in Kielce [hereinafter: ADK], Małogoszcz. Dokumenty różne z XIX wieku (luzem, nieuporządkowane) / Małogoszcz. Miscellaneous documents from the $19^{\text {th }}$ century (loose, unordered), ref. code IIPM-I/6, sheets 41-79.

Tomasz Światkowski (1786-1855) - doctor of theology, canon and official of Kielce, parish priest of Małogoszcz in 1836-1855. See ADK, Akta konsystorskie ogólne. Życiorysy kapłanów 1835 / General Consistorial Records. Lives of priests 1835, ref. code OP-X/4b, sheets 206-206v; ibidem, Consistorial files. Status of cleri 1847-1929, ref. code OP-X/13, sheets 1012-1013; and J. Wiśniews ki, Historyczny opis kościołów, miast, zabytków i pamiatek $w$ Jędrzejowskiem, Marjówka 1930 (reprint: Kielce 2000), p. 138, pp. 272-273 (p. 138 gives incorrect information that Światkowski died in 1856, and on p. 272, that he was born in 1785).

${ }^{2}$ M. Karkocha, Wystrój $i$ wyposażenie kościoła parafialnego $w$ Małogoszczu $w$ świetle inwentarza z 1856 roku, 'Przegląd Nauk Historycznych' 2017, vol. XVI, No. 1, pp. 325-362. 
and the condition of the residential and farm buildings of the parish in Małogoszcz ${ }^{3}$. The last part of this manuscript, included below, concerns the St. Anne prebend.

The edited document was recorded in Polish on sheets of paper of a size similar to A4, written on both sides, numbered from 1 to 77 (currently sheets 41-79). The writing is legible, clear, with only a handful of amendments to the text. The tally was carried out by a commission composed of representatives of laity and clergy: the Dean of Kielce, Fr. Stanisław Zygmuntowicz ${ }^{4}$, the newly elected parish priest Fr. Nestor Bieroński ${ }^{5}$, the mayor of Małogoszcz Karol Syktowski, the president of the church supervising body Jan Mieszkowski ${ }^{6}$ and two of its members - Jan Saski ${ }^{7}$ and Józef Wodzyński ${ }^{8}$. It was signed

${ }^{3}$ Eadem, Opis probostwa $w$ Małogoszczu z 1856 roku, 'Przegląd Nauk Historycznych' 2018, vol. XVII, No. 1, pp. 143-170.

${ }^{4}$ Stanisław Zygmuntowicz (1806-1866) - priest of the diocese of Kielce, ordained in 1830. Initially, he was a vicar in Kurzelów. In the years 1833-1866 he was an administrator and then a parish priest of the parish church in Złotniki. In 1841 he became the deputy dean (under-dean) and in 1846 the dean of the diocese of Kielce. See ADK, Akta konsystorskie. Status cleri 1847-1929 / Consistorial Records. Status cleri 1847-1929, ref. code OP-X/13, sheets 1284-1285; ibidem, Akta konsystorskie ogólne. Życiorysy kapłanów 1835-1840 / General Consistorial Records. Lives of priests 1835-1840, ref. code OP-X/3, sheet 30.

${ }^{5}$ Nestor Hygin Soter Bieroński (1816-1899) - priest of the diocese of Kielce and for many years lecturer at the Seminary in Kielce, parish priest of Małogoszcz in 1855-1899. Biography of this priest in: M. Karkocha, Parafia Rembieszyce 14382012. Studium z dziejów społeczności lokalnych, Łódź 2013, pp. 357-359. See ADK, Akta personalne ks. Nestora Bierońskiego 1842-1890 / Personal records of Fr. Nestor Bieroński 1842-1890, ref. code XB-19; ibidem, Consistorial Records. Status of cleri 1847-1929, ref. code OP-X/13, sheets 50-51; W. Giebartowski, Ś.p. ks. Nestor Bieroński, 'Przegląd Katolicki' 1899, vol. XXXVII, No. 18, pp. 281284; pr. S. Stuczeń, Parafia małogoska i jej ostatni proboszcz ś.p. ks. prałat ks. Nestor Bieroński, 'Przegląd Katolicki' 1899, vol. XXXVII, No. 21, pp. 328-330 and No. 22, pp. 345-346; J. Wiśniewski, op. cit., p. 273.

${ }^{6}$ Jan Mieszkowski - owner of the Cieśle village, lessee of Leśnica and Skorków. See Protocol for the election of Church Supervision in Małogoszcz from 1859, ADK, Małogoszcz. Miscellaneous documents from the $19^{\text {th }}$ century (loose, unordered), ref. code IIPM-I/6, sheet 105 .

${ }^{7}$ Jan Saski (1810-1868) - collator at the local church, from 1854 a leaseholder of extensive government estates in the Kielce county, consisting of 13 villages and settlements (Ruda, Wesoła, Młynki, Zajączków, Krawczowskie, Laski, Miedzianka, Podpolichno, Charężów, Gałęzice, Fanisławice, Fanisławiczki and Gnieździska), and earlier (in 1847-1852) owner of the nearby village Mieronice. His grave is located in the parish cemetery in Małogoszcz. See K. Zapałowa, Rodzina Stefana Żeromskiego w Świętokrzyskiem, Kielce 2003, p. 172 et seq.; M. Karkocha, Parafia Rembieszyce..., p. 72, 75; and the Protocol for the election of Church Supervision..., sheets $105-105 \mathrm{v}$.

${ }^{8}$ Józef Wodzyński - owner of an estate in Małogoszcz. See Church Supervision Selection Protocol..., sheets 105-105v. 
and authenticated with a seal on July $11 / 23,1856$ by an unknown Deputy Head of the Kielce county.

The Małogoszcz parish dates back to the first half of the $12^{\text {th }}$ century. The oldest church with the adjacent settlement was burnt down by the Tatars in 1259. After moving the city to a new location, a wooden temple of St. Nicholas the Bishop and St. Margaret the Martyred Virgin was erected. In 1342, King Casimir the Great generously endowed it with land grants in the western part of the city, a vast complex of land from the cemetery to the Pierzchnica River and the village of Popowice. The grant was supplemented with customs duties from Małogoszcz, Kurzelów and Chęciny, as well as two sanctuari [temple guardians] for the church. The present-day Church of the Assumption of the Blessed Virgin Mary - one-nave, brick and hew stone, with two side chapels and a massive tower from the west - was built in 1591-1595 on the initiative of Fr. Jakub Bieda Chrostkowic (aka Chrostkowicz, Chrostek) (15601630), a local mansionary, later pastor (parochus) and the Dean of Małogoszcz ${ }^{9}$. While still a mansionary, the priest erected a spacious house in Małogoszcz for the vicars, as well as a filial church of St. Stanislaus on the Babinek hill (consecrated in 1599) ${ }^{10}$. Moreover, while serving as a parish priest, he built a hospital church of the Holy Cross (consecrated in 1617), a hospital for the poor called Bethany and a house for the hospital parish priest (in 1609-1615). St. Anne's prebend also owes its establishment to him ${ }^{11}$.

It was erected in 1600 with the consent of King Sigismund III Vasa, the collator of the local temple. In the same year Chrostkowic

\footnotetext{
${ }^{9}$ More on the life and work of J. Bieda Chrostkowic see J. Wiśniewski, op. cit., pp. 214-231; M. Rawita-Witanowski, Dawny powiat chęcinski, ed. D. Kalina, Kielce 2001, pp. 109-119; E. Kosik, Chrostowice z Małogoszcza, 'Nasza Przeszłość' 1973, vol. XL, pp. 176-181; idem, M. Paulewicz, Budowniczy Małogoszcza Jakub Bieda Chrostkowicz, [in:] W kasztelańskim Małogoszczu. Monografia historyczno-gospodarcza Małogoszcza i okolicy, ed. E. Kosik, Kielce 1994, pp. 67-70; pr. S. Stuczeń, op. cit., 'Przegląd Katolicki' 1899, vol. XXXVII, No. 19, p. 296.

${ }^{10}$ This is confirmed by the inscription on the foundation plaque (which has already been severely damaged), placed on the eastern wall of the presbytery of the church on Babinek. The content of this inscription in: Corpus inscriptionum Poloniae, vol. I (Województwo kieleckie), ed. J. Szymański, book 2 (Jędrzejów $i$ region jędrzejowski), published, introduced and commented by B. Trelińska, Kielce 1978, No. 108, p. 108.

${ }^{11}$ See J. Wiśniewski, op. cit., p. 134 et seq.; E. Kosik, Parafia małogoska, [in:] W kasztelańskim Małogoszczu..., p. 63; idem, Chrostowice..., pp. 177-179; idem, M. Paulewicz, op. cit., p. 69.
} 
received from Samuel Dunin Wolski, the Małogoszcz parish priest, a plot of land located between the cemetery and the road to Kozłów, on which he built a brick house for the prefect. The construction cost 191 zlotys and 12 groszes. He also endowed the prebend with arable land, meadows and gardens ${ }^{12}$ that he had donated or purchased. The prebendary's duties included celebrating fraternity services, singing votive masses every Tuesday in the chapel of St. Anne, and on Fridays reading the Holy Mass and holding the collection 'pro peccatis' (for sins) alternately with one for the souls of the founders of the chapel and altar. In addition, the priest was obliged to be present in the church on Sundays and major holidays, in order to 'celebrate Mass versus populum on the current day before the altar of St. Anne ${ }^{13}$. The parish priest and the local magistrate had the right of presentation. The first prebendary was Fr. Jakub Bieda Chrostkowic.

Later on, the prebendary was given more responsibilities. He was to keep the church apparatus clean; maintain the roofs and windows of both the Chapel of St. Anne and the church on Babinek in good condition; keep the light for the needs of the brotherhood; take care of the organist's house and other buildings belonging to the prebend. In addition, he was expected to ensure that every quarter fraternity congregations attended by mansionaries were held and seniors were to be elected once a year (in December). On that occasion, the prebendary should present a report on donation and expenses of the fraternity of St. Anne. He was also to be present at the singing of the cursus of the Blessed Virgin Mary except for the time of sowing, harvest and tithing, and to preach at all the services of the fraternity. Without accepting these conditions, the candidate could neither be presented nor installed ${ }^{14}$.

Over the years, the salary of the prebend in question also increased through donations and bequests. It increased significantly at the beginning of the $19^{\text {th }}$ century, after the incorporation of the hospital parish fund (prebend of the Holy Cross). This included capital sums

12 The exact description of this bequest was published by J. Wiśniewski, op. cit., p. 153.

${ }^{13}$ Quoted in: ibidem.

${ }^{14}$ See ibidem, pp. 152-154; C. Hadamik, D. Kalina, E. Traczyński, Miasto i gmina Małogoszcz [series: Dzieje i zabytki małych ojczyzn, ed. R. Mirowski], Kielce 2006, pp. 128-129. 
bequeathed on the estates of Wodzisław, Gruszczyn, Ludynia, Żarczyce Duże and Żarczyce Małe, as well as Lasochów ${ }^{15}$.

However, let us return to our source. The first part describes the appearance and condition of residential and farm buildings of the prebend, i.e. the house of the prebendary, stables, coach house, pigsties, two barns, a hay shed, cellar, granary, vegetable and fructiferous gardens, and finally the servants' cottage. Then the arable land and meadows belonging to the fund were specified. When determining the location of the land, local topographical names were given, e.g. Bochynia mill, Pszczelnik grange (folwark), meadow in Kłysowe pits, garden near Sabianów, farmed land in Zapłocie, reeve's (wójt's) land, parish fields. The location was also determined in relation to such objects as a chapel, pottery, Mieronice pits, forest, orchards and town meadows. Roads (e.g. Karsznice, Leśnica, Chęciny, Warsaw), land owned by peasants and townsfolk, as well as grange buildings were also a point of reference. The subsequent section of the document contains information on the sowings, livestock and movable property of the prebend. The last element of the edited part of the manuscript is the list of the profits (intrata) of St. Anne's prebend according to the 1818 census.

\section{$* * *$}

The edition of the document has been prepared in accordance with the requirements of Kazimierz Lepszy's ${ }^{16}$ publishing guidelines, which recommends the modernisation of the source's spelling. The changes made concerned the use of upper and lower case letters in accordance with today's rules. The punctuation has also been corrected by adding commas to sentences as required. The vowels 'I', 'y' and consonant 'j' were used according to today's rules. Double consonants 'ss' and ' $m m$ ' have been replaced by single letters, e.g. 'kassa', 'summa', 'kommissya'. The

${ }^{15}$ See i.e. Inventory fundi instructi of the parish church beneficium in the town of Małogoszcz..., sheet 74v; J. Wiśniewski, op. cit., pp. 145-146; E. Kosik, Rozwój urbanistyczny $i$ zabudowa Małogoszcza do 1821 roku, [in:] W kasztelańskim Małogoszczu..., p. 53; and M. Karkocha, Uposażenie parafii Małogoszcz $w$ świetle sumariusza z 1792 roku, 'Przeglad Nauk Historycznych' 2016, vol. XV, No. 1, passim (source text).

${ }^{16}$ Instrukcja wydawnicza dla źródeł historycznych od XVI do połowy XIX wieku, ed. K. Lepszy, Wrocław 1953. 
'ó' character has been used according to the current spelling rules. The spelling of words ending in -em and -emi in a manuscript has been modernised, e.g. 'jednem', 'całemi' has been changed to 'jednym', 'całymi'. The word 'pulanek' is now referred to as 'półłanek' (half-łan) and the word 'skubel' is written as 'skobel' (hasp). Diacritics in letters such as 'e', 'n', 'ś', ' $\mathbf{z}$ ', ' $\dot{z}$ ' and less frequently ' 1 ' have been added to the text. In the edition, the word repeated from the previous page in the source base has been omitted. The spelling of abbreviations denoting monetary units has been unified and their contemporary equivalents have been introduced ('zp' and 'g' have been replaced by 'złp' (zlotys) and 'gr' (groszes), and 'rs' by 'rbs' (silver ruble). If the writer skipped a letter in a word, it has been added in rectangular brackets. The beginning of the page in the original and abbreviations have been marked in the same way. Letter footnotes provide information on the external form and wording of the source text, as well as uncertain readings. In the material footnotes the persons and localities mentioned in the source are explained. The emphasis on words and the division into paragraphs, such as in the manuscript, have been maintained.

As far as the graphic aspect of the text is concerned, the description of the residential and farm buildings belonging to the prebend has been drawn up based on the edition in a four-column table containing the number, the description of the buildings, the value according to estimation (in silver rubles) and notes. The last of these columns had no annotations. At the request of the editorial board, the source is not reproduced in the form of a table and information about the value of individual buildings has been included at the end of their respective descriptions. 


\title{
Description of St. Anne's prebend in Małogoszcz
}

\author{
Małogoszcz, July 5/17, 1856
}

\begin{abstract}
Or.: Diocesan Archive in Kielce, Małogoszcz. Miscellaneous documents from the $19^{\text {th }}$ century (loose, unordered), ref. code IIPM-I/6, sheets 75-78v.
\end{abstract}

[sheet 75] Description of structures

There is a separate courtyard on Włoszczowska Street, surrounded by a fence. The gate is located in the courtyard, on iron jougs, with a hasp and a latch: 1 prebend dwelling, house of cubic timber, half-covered with shingles, and half with straw, chimney of brick from the foundation. Entrance ${ }^{a}$ to the vestibule from the eastern side, through doors on hinges and iron hooks with a hasp and a latch, with an iron bolt. A small hallway, paved with stone, without wooden ceiling beams, inside this hallway there are two doors, one to the garden, on hooks and hinges, [with] a hasp and a latch, while the other lead to the chambers of servants, also on hinges, [with] a hasp, a latch and handle. In the room, the floor is made partly of wooden boards, and partly of stone, uneven, ceiling made of narrow wooden beams, the kitchen chimney made of stone, the stove heating the servants' chamber and one room, one window one with six windowpanes, on the left side of the kitchen there is a door to a small room, on iron hooks and hinges, with a handle, with a hook. A small room with a floor and a ceiling of wooden beams, from this room the door, leading to the kitchen in front of the stove, on hinges and hooks, [with] a hasp and a latch, one window, in the above described servants' chamber there a doors on iron hinges and hooks, with French lock and key, wooden floorboards in the room, wooden beams on the ceiling, a stove heating the servants' chamber and the room, one window, across from the door from the servants' chamber [sheet $75 \mathrm{v}$ ] there is a door to the pantry on iron hooks and hinges, with a hasp and a latch. In the pantry, the floor is made of wooden boards and ceiling of wooden beams, one window, on the left side of this pantry there is a door to the other pantry, on hooks and hinges, in this pantry there is a little floor, ceiling of wooden beams, a small window. In the first room described above there is a door to the second room, on iron hinges and hooks, the

\footnotetext{
a In the Polish original, there follows the word: 'od' crossed out by the author.
} 
floor made of lumber, the floor ceiling covered with wooden boards, a brick stove, two windows, opening in half. The walls, the roof and all internal details of the entire building are in the worst condition and qualify for complete demolition. Value: $70 \mathrm{rbs}$.

Pigsties. In the courtyard, in the vicinity of the gate, there are three pigsties for cattle and stock arranged at a straight angle, shingle-covered roof, in the whole structure there are three doors on wooden poles with hasps and latches, the pigsties are in good condition. Value: 30 rbs.

Stables. In the vicinity of the pigsties described above, there is a stable for horses made of processed wood, shingle-covered, with a foundation, doors on iron hooks [with] a hasp and a latch, a completely collapsed floor, a ceiling made of wooden rods, on both sides there are troughs with ladders, where four horses can stand by each side. The whole stable is in a very poor condition. Value: 20 rbs.

Basement. Behind a separate fence there is a basement, made of stone, vaulted, roof covered with shingles, small doors on iron hooks and hinges, [with] a hasp and a latch, the roof over this basement is in a very bad condition, hence the entire basement has been destroyed. [sheet 76]

Hay shed attached to the barn, three walls in part made of rods, in part of logs, in part of poles, roof covered with straw, double gate on poles, in bad shape, with a hasp and a latch, the whole building is in an average condition.

The first barn. There are two barns in close proximity to each other, the first one near the hay shed, timber quoin, on a foundation, thatched with straw. Double door on poles, iron jougs, [with] a hasp and a latch, one threshing floor, two side bays. This barn is in a very bad condition, intended for repositioning. Value: $40 \mathrm{rbs}^{\mathrm{c}}$.

The second barn. Next to this barn, across the yard, there is another barn, from cubic timber, on a foundation, thatched with straw, double gates on both sides, on iron jougs, with a hasp and a latch,

b In the source text: 'obudwu'.

c Total value of hay shed and first barn, bracketed in the source text. 
one threshing floor and two side bays. Walls in this are quite good, the gates and the roof are in a very bad condition. Value: 50 rbs.

Carriage house. In place of the carriage house included in the last inventory, estimated at 70 zlotys, there is a woodshed without foundation, placed on pillar, partly covered with shingles, and partly thatched with straw, door on poles, with iron, a hasp and a latch, in a very bad condition, it may collapse any time. Value: 30 rbs.

Granary. In the vicinity of the above carriage house, i.e. the woodshed, there is a granary, on a timber foundation, quoined, thatched with straw, doors on hinges and iron hooks, with a French lock, with a key, a hasp, a latch, with an iron door knocker. The whole floor, [sheet 76v] and ceiling made of sawn timber boards and beams, with seven huches of sawn timber and logs, stairs to the top, entrance upstairs by means of a door on the poles, with iron door knocker, a hasp and a latch. The whole granary is in a poor condition. Value: 40 rbs.

Gardens. Within the fence of the prebend there are four gardens, one $^{\mathrm{d}}$ adjacent to the mansionary, the other in the yard, the third through the front windows, the fourth, fructiferous, outside the prebend, in which there are several cherry and plum trees.

Cottage, property of the prebend. In the street leading to the village of Leśnica, there is a twin cottage made of hewn logs, erected on a foundation, shingle-covered, one masonry chimney over the roof, this cottage has one hallway in the middle, with two doors on both sides on hinges, with hasps and latches. There are two chambers on both sides of this hallway, of which there are two rooms, from which there is entrance to two chambers, and there are doors on poles, with hasps and latches, there are no floors, the ceiling is made of timber beams, there are two windows in each room, as well as chimneys, stoves and ovens. The whole cottage is in quite good condition. There are only two walls and two posts left from the cowshed adjoining the cottage. Value: 40 rbs.

Garden. Adjoining the above building is a vegetable garden. [sheet 77]

\footnotetext{
d In the source text: 'jedyn'.
} 


\section{Description of the land, property of the prebend}

The half-lane of the field by the Leśnica $\operatorname{road}^{17}$ directly opposite the shrine under the pear trees, three furlongs long, bordered by the Leśnica road and Kazimierz Rynkowski on the other side ${ }^{18}$.

The second half-lane next to the Leśnica road, three furlongs, bordered by the land of Kacper Skrobot ${ }^{19}$ in the north and Józef Kaminski in the south.

Halfway further towards Leśnica stand four, bordered on the south by Józef Kamiński's ${ }^{20}$ land on the north, and Józef Nowaczek's ${ }^{21}$ land from the south.

The half-lane in Zapłocie by pottery stoves, six furlongs, borders on the western side with the land of Stanisław Karniowski ${ }^{22}$, and on the eastern side with the land of Jan Nowaczek' ${ }^{23}$ successors.

The half-lane by the Chęciny ${ }^{24}$ road through the Karsznice ${ }^{25}$ road to the borders of Mieronice ${ }^{26}$, borders with the land of several townsmen of Małogoszcz.

The half-lane field among the fields called from the Checciny road, from the Karsznice road to the Mieronice borders, borders with the land of several townsmen of Małogoszcz.

Along the Chęciny road, walking from the city on the left, there is one furlong-wide arable land of only eleven acres (zagony), bordered from the west by the land of Józef Pieczyżaba ${ }^{27}$, from the east by the land of Piotr Fabryczny ${ }^{28}$, and two half-lanes in Kozubowo.

${ }^{17}$ Leśnica - village in the Jędrzejów county, $3 \mathrm{~km}$ north of Małogoszcz.

${ }^{18}$ Kazimierz Rynkowski - burgher, otherwise unknown.

${ }^{19}$ Kacper Skrobot - burgher, otherwise unknown.

${ }^{20}$ Józef Kamiński - Małogoszcz burgher, otherwise unknown.

${ }^{21}$ Józef Nowaczek - burgher from Małogoszcz, otherwise unknown.

${ }^{22}$ Stanisław Karniowski - burgher from Małogoszcz, otherwise unknown.

${ }^{23}$ Jan Nowaczek - burgher from Małogoszcz, otherwise unknown.

${ }^{24}$ Checciny - city in the Kielce county, about $15 \mathrm{~km}$ east of Małogoszcz.

${ }^{25}$ Karsznice - village in the Jędrzejow county, about $6 \mathrm{~km}$ southeast of Małogoszcz.

${ }^{26}$ Mieronice - village in the Jędrzejów county, bordering with the land of the town of Małogoszcz.

${ }^{27}$ Józef Pieczyżaba - burgher, otherwise unknown. This surname appears in the $17^{\text {th }}$ century Małogoszcz sources. In 1630 a certain Adam Pieczyżabka sold the tillable land to Fr. Jakub Chrostkowic, on which the annual rent was paid to the hospital parish priest. See J. Wiśniewski, op. cit., p. 141; M. Karkocha, Uposażenie parafii Małogoszcz..., p. 257.

${ }^{28}$ Piotr Fabryczny - burgher from Małogoszcz, otherwise unknown. 
The half-lane of arable land behind the town orchards sic furlongs towards the Mieronice pits, and two behind the pits, bordered by the land of the reeve from the east, and from the west by the land of Wincenty Watorski ${ }^{29}$.

The half-lane of two furlongs of arable land, in the Muszny pit, by the road to Kozłów ${ }^{30}$, borders on the east with the town Ściegna ${ }^{\mathrm{e}}$, and on the west with the land of the City Treasury.

Garden near Sabianów ${ }^{31}$ for cabbage and other vegetables and such, newly fenced off with a rod fence, bordered by the parish fields, and from the north by the road to Kozłow leaning from the town. [sheet $77 \mathrm{v}$ ]

\section{Meadows belonging to the prebend}

The pasture behind the town by the barns of Mr Klimkiewicz ${ }^{32}$ all fenced, with good hay, borders to the south with the road to Checciny, to the east with the meadow [and] with the barn of Mr Klimkiewicz, to the east with the garden of Antoni Skrobot ${ }^{33}$, and to the north with the meadow of Jan Jaworski ${ }^{34}$.

The smaller pasture, also with hay, outside the town, right next to the Warsaw road, bordered to the west with town houses, to the east with a meadow and a Dabek's garden.

The meadow by the Bochynia mill, known as the Bochynia mill, borders on the Młynarska meadow in the west, and on the east on the town meadows.

The meadow by the grange called Pszczelnik, bordered from the west by the grange buildings of Mr Rożański ${ }^{35}$, from the east by the town meadows.

The meadow in Cieszczyn ${ }^{36}$ borders with town fields and meadows.

\footnotetext{
e Only an approximated reading.

${ }^{29}$ Wincenty Watorski - burgher, otherwise unknown.

${ }^{30}$ Kozłów - village in the Jędrzejów county, about $7 \mathrm{~km}$ west of Małogoszcz.

${ }^{31}$ Sabianow - formerly the name of the forest, now one of the streets in Małogoszcz.

${ }^{32}$ Klimkiewicz - burgher from Małogoszcz, otherwise unknown.

${ }^{33}$ Antoni Skrobot - burgher, otherwise unknown.

${ }^{34}$ Jan Jaworski - burgher from Małogoszcz, otherwise unknown.

${ }^{35}$ Rożański - burgher from Małogoszcz, otherwise unknown.

${ }^{36}$ Unidentified town.
} 
Meadow in Kłysowe ${ }^{\mathrm{f}}$ pits, bordered from the west by the meadows of the Ruda Narodowa ${ }^{37}$ manor house, to the north by the land of the peasants from village of $\mathrm{Młynki}^{38}$, to the east by the town forest, and to the south by the town meadows.

\section{Sowing pro fundo instructo}

\begin{tabular}{|c|l|c|c|}
\hline No. & \multicolumn{1}{|c|}{ Specification of the sowing type } & $\begin{array}{c}\text { Number } \\
\text { of acres }\end{array}$ & Comments \\
\hline & Grain sowings pro fundo instructo are as follows \\
\hline 1 & Wheat sowing & 208 & \\
\hline 2 & Rye sowing & 372 & \\
\hline 3 & Barley sowing & 150 & \\
\hline 4 & Oats sowing & 116 & \\
\hline 5 & Peas sowing & 42 & \\
\hline 6 & Tartary buckwheat sowing & 36 & \\
\hline 7 & Potatoes planted & 4 & \\
\hline 8 & Cabbage planted & & \\
\hline
\end{tabular}

[sheet 78] List

inventory and movables of St. Anne's prebend in Małogoszcz

\begin{tabular}{|c|c|c|c|c|c|}
\hline \multirow{2}{*}{ No. } & \multirow{2}{*}{ Specification of items } & \multirow{2}{*}{$\begin{array}{l}\text { Found } \\
\text { upon } \\
\text { making } \\
\text { this } \\
\text { registry }\end{array}$} & \multicolumn{2}{|c|}{$\begin{array}{l}\text { Value as } \\
\text { estimated }\end{array}$} & \multirow{2}{*}{ Comments } \\
\hline & & & zloty & gr & \\
\hline & \multicolumn{5}{|l|}{$\underline{\text { For livestock }}$} \\
\hline 1 & $\begin{array}{l}\text { One pair of oxen, one dapple, } \\
\text { the other plain, both these } \\
\text { steers are old }\end{array}$ & 2 & 171 & & \\
\hline
\end{tabular}

${ }^{\mathrm{f}}$ The reading of this word in only an approximation.

${ }^{37}$ Reference to Ruda Zajaczkowska - village in the Kielce county, about $8 \mathrm{~km}$ north-east of Małogoszcz. In the past this village used to be called Ruda Narodowa or Ruda Rządowa.

${ }^{38}$ Młynki - hamlet of the village of Wesola in the Kielce county, about $6 \mathrm{~km}$ to the northeast from Małogoszcz. 


\begin{tabular}{|c|l|c|c|c|l|}
\hline & For domestic appliances \\
\hline 1 & Iron cauldron for 10 pots & 1 & 20 & & $\begin{array}{l}\text { Losses in } \\
\text { comparison }\end{array}$ \\
\hline 2 & Roof chimney ladder & 1 & 1 & & \\
\hline
\end{tabular}

\section{$\underline{\text { List }}$}

the profit of St. Anne's prebend together with the mansionarium in Małogoszcz according to the lay and clergy census on November 21, 1818, drawn up by the Lay and Clergy Committee

\begin{tabular}{|c|c|c|c|c|}
\hline \multirow[t]{2}{*}{ No. } & \multirow[t]{2}{*}{ List of revenue and expenditure } & \multicolumn{2}{|c|}{$\begin{array}{l}\text { Amount of } \\
\text { money }\end{array}$} & \multirow[t]{2}{*}{ Comments } \\
\hline & & zloty & gr & \\
\hline & \multicolumn{4}{|l|}{ From tithes } \\
\hline 1 & $\begin{array}{l}\text { Tithe from the town of Małogoszcz from } \\
\text { unused land called 'dugouts', which is } \\
\text { collected in grain, four sacks of rye }\end{array}$ & & & \\
\hline \multirow[t]{2}{*}{2} & $\begin{array}{l}\text { Tithe from Bochynia miller's land } \\
\text { twenty-four pots of rye }\end{array}$ & & & \\
\hline & \multicolumn{4}{|l|}{ Money tithes } \\
\hline 1 & $\begin{array}{l}\text { Tithe from the reeve of the village of } \\
\text { Leśnica }\end{array}$ & 52 & $261 / 2$ & \\
\hline 2 & $\begin{array}{l}\text { Tithe from the peasants of the village of } \\
\text { Przygradów }\end{array}$ & 20 & & \\
\hline \multirow[t]{2}{*}{3} & $\begin{array}{l}\text { Tithe from the villages Zajaczków }{ }^{40} 18, \\
\text { Wesoła }^{41} \text { and Ruda }{ }^{42} 12 \text { złp }\end{array}$ & 30 & & $\begin{array}{l}\text { Collected } \\
\text { together }\end{array}$ \\
\hline & \multicolumn{4}{|l|}{$\underline{\text { From capitals }}$} \\
\hline 1 & $\begin{array}{l}\text { From the sum of } 20,000 \mathrm{zlp} \text { placed } \\
\text { on the Nieznanowice }{ }^{43} \text { estate, the } \\
\text { percentage of } 4 / 100 \text { is collected from } \\
\text { the government }\end{array}$ & 800 & & \\
\hline
\end{tabular}

${ }^{39}$ Przygradów - village in the Włoszczowa county, about $17 \mathrm{~km}$ west of Małogoszcz.

${ }^{40}$ Zajaczzkow - village in the Kielce county, about $9 \mathrm{~km}$ north-west of Małogoszcz.

${ }^{41}$ Wesola - village in the Kielce county, about $7 \mathrm{~km}$ north-east of Małogoszcz.

${ }^{42}$ Ruda Zajaczkowska - village in the Kielce county, $9 \mathrm{~km}$ north of Małogoszcz.

${ }^{43}$ Nieznanowice - village in the Włoszczowa county, $18 \mathrm{~km}$ west of Małogoszcz. 


\begin{tabular}{|c|c|c|c|c|}
\hline 2 & $\begin{array}{l}\text { From the sum of } 1000 \mathrm{zlp} \text { placed on } \\
\text { the Ludynia }{ }^{44} \text { estate, the percentage } \\
\text { of } 4 / 100 \text { is also collected from the } \\
\text { government }\end{array}$ & 40 & & \\
\hline 3 & $\begin{array}{l}\text { From the sum of } 3400 \mathrm{zlp} \text { placed on the } \\
\text { Czartoszowy }{ }^{45} \text { estate, the percentage of } \\
4 / 100 \text { is collected from the government }\end{array}$ & 136 & & \\
\hline 4 & $\begin{array}{l}\text { From the sum of } 3000 \mathrm{zlp} \text { placed on the } \\
\text { Kluczewsko }{ }^{46} \text { estates, the percentage of } \\
4 / 100 \text { is collected from the government }\end{array}$ & 120 & & \multirow{3}{*}{$\begin{array}{l}\text { Of this sum } \\
{\left[^{\mathrm{g}}\right] \text { is paid on }} \\
\text { the great } \\
\text { altar } 85 \mathrm{złp} \text {, } \\
\text { to paupers } \\
15 \mathrm{zlp}\end{array}$} \\
\hline 5 & $\begin{array}{l}\text { From the sum of } 2000 \mathrm{zlp} \text { placed on the } \\
\text { Gruszczyn }{ }^{47} \text { estate, the percentage of } \\
4 / 100 \text { is paid from the government }\end{array}$ & 80 & & \\
\hline 6 & $\begin{array}{l}\text { From the sum of } 1500 \mathrm{zlp} \text { placed on } \\
\text { Żarczyce }{ }^{48} \text { estate, the percentage of } \\
4 / 100 \text { is collected from the government }\end{array}$ & 60 & & \\
\hline 7 & $\begin{array}{l}\text { From the sum of } 1500 \mathrm{zlp} \text { placed on the } \\
\text { Lasochów }{ }^{49} \text { estate, the percentage of } \\
5 / 100 \text { is collected from the squire }\end{array}$ & 75 & & \\
\hline 8 & $\begin{array}{l}\text { From the sum of } 160 \mathrm{złp} \mathrm{placed} \mathrm{on} \\
\text { Józefa Wodzyńska's }{ }^{50} \text { house } 5 / 100\end{array}$ & 8 & & \\
\hline 9 & $\begin{array}{l}\text { Land inventory according to the lay and } \\
\text { clergy census }\end{array}$ & 58 & 15 & \\
\hline 10 & According to the list as above, intrata & 44 & & \\
\hline & Total revenue & 1524 & $11 \frac{1}{2}$ & \\
\hline & ${ }^{\mathrm{h}}$ Or 228 silver rubles $65^{3 / 4}$ kopeykas ${ }^{\mathrm{h}}$. & & & \\
\hline
\end{tabular}

g Illegible word.

${ }^{\text {h-h }}$ Handwritten in a different hand.

${ }^{44}$ Ludynia - village in the Włoszczowa county, about $11 \mathrm{~km}$ north-west of Małogoszcz.

${ }^{45}$ Czartoszowy - village in the Kielce county, $12 \mathrm{~km}$ north of Małogoszcz.

${ }^{46}$ Kluczewsko - village in the Włoszczowa county, about $37 \mathrm{~km}$ north-west of Małogoszcz.

${ }^{47}$ Gruszczyn - village in the Włoszczowa county, about $10 \mathrm{~km}$ north-west of Małogoszcz.

${ }^{48}$ Reference to Żarczyce Duże and Żarczyce Małe - both these localities in the Jędrzejow county, 4 and $8 \mathrm{~km}$ south-west of Małogoszcz. The amount was bequeathed on his estate by Jerzy Konarski, Gryf coat of arms (1642-1705) in 1699. See M. Karkocha, Uposażenie parafii Małogoszcz..., p. 274.

${ }^{49}$ Lasochów - village in the Jędrzejów county, $6 \mathrm{~km}$ south-east of Małogoszcz.

50 Józefa Zbudzyńska - burgher woman from Małogoszcz, otherwise unknown. 


\section{Bibliography}

\section{Archival sources}

Archiwum Diecezjalne w Kielcach [ADK]

(Diocesan Archive in Kielce)

Akta konsystorskie. Status cleri 1847-1929 / Consistorial Records. Status cleri 1847-1929, ref. code OP-X/13.

Akta konsystorskie ogólne. Życiorysy kapłanów 1835 / General Consistorial Records. Lives of priests 1835, ref. code OP-X/4b.

Akta konsystorskie ogólne. Życiorysy kapłanów 1835-1840 / General Consistorial Records. Lives of priests 1835-1840, ref. code OP-X/3.

Akta personalne ks. Nestora Bierońskiego 1842-1890 / Personal records of Fr. Nestor Bieroński 1842-1890, ref. code XB-19.

Małogoszcz. Dokumenty różne z XIX wieku (luzem, nieuporządkowane) / Małogoszcz. Miscellaneous documents from the $19^{\text {th }}$ century (loose, unordered), ref. code IIPM-I/ 6 .

\section{Printed sources}

Corpus inscriptionum Poloniae, vol. I (Województwo kieleckie), ed. J. Szymański, book 2 (Jędrzejów i region jędrzejowski), published, introduced and commented by B. Trelińska, Kielce 1978.

\section{STUdies}

Giebartowski W., Ś.p. ks. Nestor Bieroński, 'Przegląd Katolicki' 1899, XXXVII, No. 18, pp. 281-284.

Hadamik C., Kalina D., Traczyński E., Miasto i gmina Małogoszcz, Kielce 2006 (series: Dzieje i zabytki małych ojczyzn, ed. R. Mirowski, vol. V).

Instrukcja wydawnicza dla źródeł historycznych od XVI do połowy XIX wieku, ed. K. Lepszy, Wrocław 1953.

Karkocha M., Opis probostwa w Małogoszczu z 1856 roku, 'Przegląd Nauk Historycznych' 2018, vol. XVII, No. 1, s. 143-170.

Karkocha M., Parafia Rembieszyce 1438-2012. Studium z dziejów społeczności lokalnej, Łódź 2013.

Karkocha M., Uposażenie parafii Małogoszcz $w$ świetle sumariusza z 1792 roku, 'Przegląd Nauk Historycznych' 2016, vol. XV, No. 1, pp. 249-276.

Karkocha M., Wystrój i wyposażenie kościoła parafialnego w Małogoszczu w świetle inwentarza z 1856 roku, 'Przegląd Nauk Historycznych' 2017, vol. XVI, No. 1, pp. 325-362.

Kosik E., Chrostowice z Małogoszcza, 'Nasza Przeszłość' 1973, vol. XL, pp. 175-182.

Kosik E., Parafia małogoska, [in:] W kasztelańskim Małogoszczu. Monografia historyczno-gospodarcza Małogoszcza i okolicy, ed. E. Kosik, Kielce 1994, pp. 59-66. 
Kosik E., Rozwój urbanistyczny i zabudowa Małogoszcza do 1821 roku, [in:] W kasztelańskim Małogoszczu. Monografia historyczno-gospodarcza Małogoszcza i okolicy, ed. E. Kosik, Kielce 1994, pp. 47-57.

Kosik E., Paulewicz M., Budowniczy Małogoszcza Jakub Bieda Chrostkowicz, [in:] W kasztelańskim Małogoszczu. Monografia historyczno-gospodarcza Małogoszcza i okolicy, ed. E. Kosik, Kielce 1994, s. 67-70.

Rawita-Witanowski M., Dawny powiat chęciński, ed. D. Kalina, Kielce 2001.

Stuczeń S. pr., Parafia małogoska i jej ostatni proboszcz ś.p. ks. prałat ks. Nestor Bieroński, 'Przegląd Katolicki' 1899, vol. XXXVII, No. 19, pp. 296-297; No. 21, pp. 328-330; No. 22, pp. 345-346.

Wiśniewski J., Historyczny opis kościołów, miast, zabytków i pamiatek $w$ Jędrzejowskiem, Marjówka 1930 (reprint: Kielce 2000).

Zapałowa K., Rodzina Stefana Żeromskiego w Świętokrzyskiem, Kielce 2003. 